\title{
$\nabla$ \\ IJCRR \\ Section: Healthcare \\ Screening the Effect of Environmental Hazards on Pulmonary Function and Health Risk Biomarkers in Cotton Industry Workers
}

ISI Impact Factor

(2019-20): 1.628

IC Value (2019): 90.81

$\operatorname{SJIF}(2020)=7.893$

(c) (1) (8)

Copyright@IJCRR

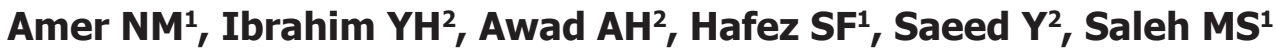

'Environmental and Occupational Medicine Department, Environmental Research Division, National Research Centre, Dokki, Giza, Egypt; ${ }^{2}$ Air Pollution Research Department, Environmental Research Division, National Research Centre, Dokki, Giza, Egypt.

\section{ABSTRACT}

Introduction: The textile industry is one of the main industries that support the Egyptian economy as it shares with about 10 per cent of the country's exports. ${ }^{1}$ Workers in the textile industry are occupationally exposed to many health hazards that invite serious interference

Objectives: Workers in the cotton industry are occupationally exposed to environmental hazards that negatively affect their health. Assessment of environmental exposures and health risk predictors for screening purposes is crucial to maintain a healthier workplace.

Methods: Fifty-two workers in the cotton weaving and spinning section were included in the study. Clinical investigations included pulmonary function tests and measurement of blood pressure after obtaining medical history and socio-demographic data. Serum samples were obtained for biochemical estimation of cortisol, a-amylase and IL-6 using the ELISA technique. Environmental assessments included noise level, presence of fibres, and particulate matter.

Results: Particulate matter did not exceed approved limits where TSP ranged between 1.25 and $1.80 \mathrm{mg} / \mathrm{m}^{3}$ at four different sites while $\mathrm{PM}_{10}$ ranged between 1.65 and $1.95 \mathrm{mg} / \mathrm{m}^{3}$. Fibres concentration with aspect ratio 3:1 was $0.01 \mathrm{~F} / \mathrm{CC}$, long axis fibres range was 9-13 micrometre and short-axis fibres range was 2-7 micrometre. Noise level exceeded the permitted level with a mean of $105.5 \mathrm{~dB}$. Abnormal spirometry was detected in $20 \%$ of the sample with the mean value of 3.4 for FEV and 6.6 for the PEF for the whole sample. Cortisol means value $(242.3 \mathrm{ng} / \mathrm{ml})$ exceeded the upper normal limit as well as that of $\alpha$-amylase (1001.5 U/L) and IL-6 mean value was $0.075 \mathrm{pg} / \mathrm{ml}$.

Conclusions: Reported respiratory and hearing complaints, abnormal spirometry, increased levels of serum cortisol and a-amylase and reduced level of IL-6 could alarm for serious risk of health deterioration among cotton industry workers that invites continuous checkup for workers' health and monitoring of environmental hazards.

Key Words: Cotton industry workers, Stress, Particulate Matter, Noise, Pulmonary Function Tests

\section{INTRODUCTION}

The textile industry is one of the main industries that support the Egyptian economy as it shares with about 10 per cent of the country's exports. ${ }^{1}$ Workers in the textile industry are occupationally exposed to many health hazards that invite serious interference. ${ }^{2}$ Air pollution with cotton dust -produced while handling cotton- can induce lung diseases, byssinosis, pulmonary fibrosis, and chronic obstructive pulmonary disease. ${ }^{3}$ Other respiratory problems due to exposure of workers to particulate matter (PM) include altered pulmonary functions and symptoms of chest tightness. ${ }^{4}$ Small particulates can also penetrate the lungs reaching blood-stream carrying toxins to all parts of the body affecting both respiratory and cardiovascular systems. ${ }^{5,6}$

As reported, risks of cardiovascular diseases due to the exposure to fine particles include heart and stroke attacks with the stimulation of inflammatory responses that may interrupt heartbeats and increase the coagulation leading to premature death. ${ }^{7}$ Hypertension is also found to be associated with chronic exposure to $\mathrm{PM} .{ }^{8}$ Besides, particulate matter is suspected to cause endocrine disruption leading to the development of metabolic diseases like obesity and diabetes mellitus that interns increase the risk of cardiovascular disease. ${ }^{9}$

\section{Corresponding Author:}

Dr. Mai Sabry Saleh, 33 Elbehouth street, Environmental and Occupational Medicine Department, Environmental Research Division, National Research Centre, Dokki, Giza, Egypt, Postal code:12622; Email: nouranomer@gmail.com

ISSN: 2231-2196 (Print)

Received: 06.12 .2020
ISSN: 0975-5241 (Online)

Revised: 12.02 .2021
Accepted: 08.04.2021
Published: 20.07 .2021 
Inflammatory responses induced by chronic exposure to PM could explain some of the biological mechanisms underlying their toxic effects. Recent research reveals an increase in circulating levels of interleukin-6 (IL-6), GranulocyteMacrophage Colony-Stimulating Factor, C-reactive protein, fibrinogen, Tumor Necrosis Factor- $\alpha$ and other inflammatory and pro-inflammatory mediators in response to environmental exposure to PM. ${ }^{10}$ According to literature, three hypotheses are proposed to explain pathogenesis induced by PM that involves inflammatory responses. ${ }^{11}$. One suggestion states that activate inflammatory responses directly in the lung followed by spill-over effect leading to systemicinflammation. Others suggest the activation of sensory receptors in the lung through inhalation of a PM that affects the autonomic nervous system and stimulates the sympathetic pathways with subsequent disturbances on the cardiovascular system.A third assumption suggests that ultrafine particles interact directly with target tissues, yet it is still controversial.

Excessive noise in the working environment of textile industry represents another occupational exposure with the threat of loss of hearing. ${ }^{12}$ Besides,noise could induce stress with negative health effects including catabolism and intestinal problems, immune suppression, cardiovascular diseases and insulin resistance due to the longer-lasting activation of the hypothalamic-pituitary-adrenal (HPA) axis. ${ }^{13}$

Shift work has also been regarded as one of the most hazardous risk factors in the work environment. ${ }^{14}$ It disrupts circadian rhythm affecting health and wellbeing and predisposing to heart problems and other chronic diseases..$^{15}$ Moreover, evidence states that stress levels among workers are increased by work pattern and some researchers attribute it to disruption in social and family relationships in consequence to shift work. ${ }^{16}$ Cortisol and $\alpha$-amylase are among the most popular biomarkers of stress. The HPA-axis is dedicated to mediate body responses towards physical and mental stress and regulates the release of cortisol, ${ }^{17}$ while $\alpha$-amylase increases in blood after pharmacological activation of the adrenergic pathways triggering the sympathetic receptors as a response to physical stress.

Developing countries are greatly in shortage of good knowledge of such kinds of hazards. ${ }^{18} \mathrm{~A}$ serious attention to the health situation of cotton textile workers and underlying environmental hazards are a factual urgency. This could help to identify aspects of health needs as they provide a guide upon setting workplace health programs, identifying key issues impacting the health of working staff, planning workplace health initiatives, and helping to emphasize workers commitment and level of engagement. ${ }^{19}$

Hence, the present work is a screening study for assessment of environmental hazards (particulate matter, fibres, shift work and noise) and health risk predictors including clinical (pulmonary function and blood pressure) and biochemical (cortisol, $\alpha$-amylase and, IL-6)factors among cotton-weaving and spinning workers.

\section{METHODS}

\section{Participants}

The study was carried on workers in the weaving and spinning section (open-end spinning process) at the cotton textile factory at Giza governorate. Fifty-two participants-representing the full capacity of the morning shift- were subjected to all of the investigations, and were included in the study. Participants were interviewed where their age, working years (exposure duration) and health complaints (headache, hearing problems, respiratory and cardiac complaints) were recorded. Work is on three shifts per day ( $8 \mathrm{hr}$ each) where each worker works on the same shift for one week and transfer to the other shift time on the following week on a rotatory basis. Body mass index (BMI) was calculated after weight and height measured for all participants as kilograms per square meter. Both clinical examination and blood sampling for assessment of relevant biomarkers were performed in accordance with ethical considerations and after receiving approval (with number 16/401) from the ethical committee of the National Research Centre (NRC) and consent from all participants.

\section{Blood sampling and Biochemical assessments}

Blood samples $(5 \mathrm{ml})$ were obtained from participants using sterile plastic syringes on sterile test tubes and left for 30 min at room temperature to coagulate, then centrifuged at $3000 \mathrm{rpm}$ for 10 minutes. The separated serum was divided into several aliquots and kept frozen at $-80^{\circ} \mathrm{C}$ to be used for biochemical analysis.

Biochemical markers assessed for cotton industry workers at the open end area included cortisol, estimated by ELISA method, kit supplied from Perfect Ease Biotech (Beijing) Co., Ltd. and IL-6, estimated by ELISA method, using the kit supplied from lab science, USA. Serum $\alpha$-amylase was determined using the colourimetric kit (Biodiagnostic, Egypt).

\section{Clinical examination}

\section{Blood pressure measurement:}

Systolic and diastolic blood pressures(SBP and DBP, respectively) were measured twice using a standard mercury sphygmomanometer for all participants while sitting, then average readings were calculated.

\section{Pulmonary function tests:}

Determination of Pulmonary Ventilatory Function was done using a portable spirometer Model Smart pft USB. Serial number, name, date of birth, height and weight were recorded as personal data. Upon examination, each individual 
was asked to breathe normally from 5 to 7 times, then take a deep breath slowly and expire till the end very slowly. Participants were then asked to breathe at a normal rate again 5 to 7 times. Concerning the forced expiratory function, subjects were instructed to breathe normally 5 to 7 times, then to inspire deeply as maximum as possible, then expire forcibly till the end of expiration. They were asked to breathe normally again 5 to 7 times. The test was repeated three times as a minimum for accuracy.

\section{Environmental assessments}

\section{Measurements of particulate matter:}

Total suspended particulates (TSP) and respirable particulates $\left(\mathrm{PM}_{10}\right)$ were measured by using HAZ-DUST (American instrument) with continuous monitoring for the morning shift work at four different sites; the opening of cotton bales (site 1), weaving sections (open end) (sites 2\&3) and humidification room (site 4). The standard limits for TSP and $\mathrm{PM}_{10}$ are $10 \mathrm{mg} / \mathrm{m}^{3}$ and $3 \mathrm{mg} / \mathrm{m}^{3}$, respectively according to Egyptian environmental law 4/1994.

\section{Assessment of the presence of fibres:}

According to NIOSH method No $7400,{ }^{20}$ for a period varying between $60-120 \mathrm{~min}$. at a flow rate of $5 \mathrm{~L} / \mathrm{min}$., air samples were collected on membrane fibres $(0.45$-micrometer pore size, 25-millimetre diameter) mounted on an open face fibre holder. Samples were then stored after collection in sealed boxes in the upward position and sent for analysis in the air pollution laboratory at NRC. The membrane filters were made transparent by mounting in immersion oil.

The analysis was done for the presence of fibres at a magnification of 400Xusing phase-contrast microscopy (Olympus, Tokyo, Japan). Fibres were considered for counting using Walton Beckett reticule in the eyepiece if they had the dimensions of $>5 \mu \mathrm{m}$ in length and $<3 \mu \mathrm{m}$ in diameter and aspect ratio $3: 1$.

\section{Measurement of sound level:}

Environmental noise assessment was done using a portable Sound Level Meter Standard (Model CR 306). Measurements were performed at different sites in the open-end spinning sector then the average was calculated.

\section{Statistical analysis}

Statistical analysis for data included descriptive means and standard deviation, frequency distribution, and student t-test for comparing means. The statistical package for social sciences, version 22 for windows (SPSS Inc., USA) was used.

\section{RESULTS}

In Table 1, the study sample showed a mean age of 39 years with a mean work history of 17 years.
SBP, DBP, and HR showed to be within normal and the mean value for BMI exceeded limits of normal body weight. The cortisol mean value (242.3ng/ $\mathrm{ml}$ ) exceeded the upper normal limit(normal range: $50-230 \mathrm{ng} / \mathrm{ml}$ ), the mean value for $\alpha$-amylase was a burst and reached 1001.5 U/L (normal range: 70$340 \mathrm{U} / \mathrm{L}$ ) and IL-6 mean value for the study population showed to be $0.075 \mathrm{pg} / \mathrm{ml}$ proposing immunosuppression.

Hearing and respiratory complaints were mostly addressed with $35 \%$ and $33 \%$, respectively followed by headache $(25 \%)$ and finally cardiac complaints $(15 \%)$ as shown in figure 1.

Table 1: Descriptive data of study variables.

\begin{tabular}{|c|c|c|c|}
\hline Variable (N) & Mean \pm S.D & Minimum & Maximum \\
\hline Age (52) & $39.3 \pm 6.9$ & 23 & 60 \\
\hline Exposure (52) & $17.1 \pm 5.9$ & 6 & 29 \\
\hline BMI (44) & $26.8 \pm 4.2$ & 20 & 39 \\
\hline $\operatorname{SBP}(46)$ & $132 \pm 19$ & 90 & 180 \\
\hline DBP (46) & $84 \pm 12$ & 60 & 110 \\
\hline HR (47) & $76.2 \pm 13.6$ & 48 & 108 \\
\hline $\begin{array}{l}\text { Cortisol (ng/ml) } \\
(50)\end{array}$ & $242.3 \pm 100.0$ & $35 \cdot 7$ & 410.90 \\
\hline $\begin{array}{l}\alpha \text {-amylase }(\mathrm{U} / \mathrm{L}) \\
(52)\end{array}$ & $1001.5 \pm 242.9$ & 551.6 & 1479.6 \\
\hline IL-6 $(\mathrm{pg} / \mathrm{ml})(45)$ & $0.075 \pm 0.069$ & 0.00 & 0.34 \\
\hline
\end{tabular}

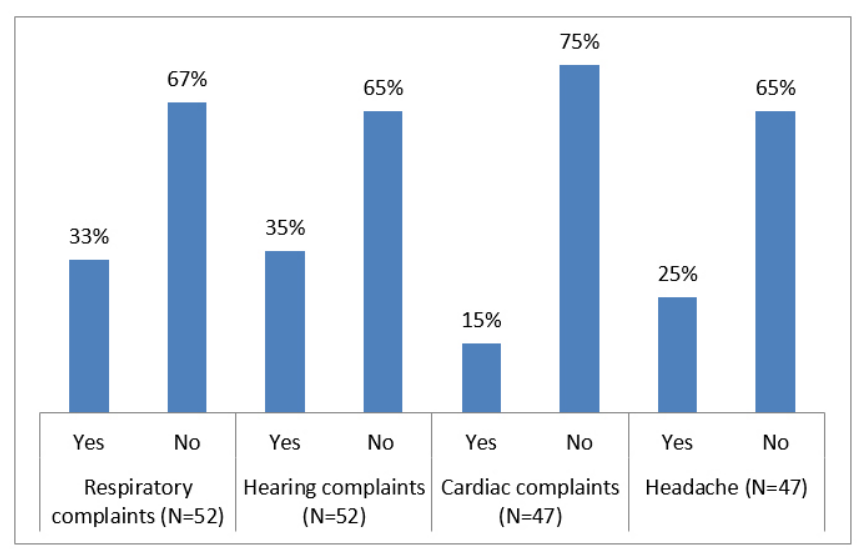

Figure 1: Percentages of different health complaints reported by study sample where $33 \%$ declared respiratory complaints, $35 \%$ showed hearing complaints, $25 \%$ had a headache and only $15 \%$ suffered from cardiac problems.

According to Pulmonary function tests, workers with abnormal spirometry functions represented 9 out of 44 workers $(20 \%)$ who performed the test. Preliminary results are listed in Table 2 as mean, and standard deviation for vital capacity (VC), Forced expiratory volume in the first second (FEV1), 
Peak expiratory flow (PEF), and Mid expiratory flow (MRF); $25 \%, 50 \%$ and $75 \%$. Compared means of the aforementioned parameters between workers with normal and abnormal spirometry functions are also shown in Table 2.

Table 2: Descriptive Statistics and compared means for spirometry indices.

\begin{tabular}{|c|c|c|c|c|}
\hline & Spirometer function & Mean & Min/Max. & P value \\
\hline \multirow[t]{3}{*}{$\mathrm{VC}(\mathrm{L})$} & Normal (35) & $4.3 \pm 0.6$ & - & 0.059 \\
\hline & Abnormal (9) & $3.9 \pm 0.6$ & - & \\
\hline & Total (44) & $4.3 \pm 0.6$ & $2.9 / 5.4$ & - \\
\hline \multirow[t]{3}{*}{$\mathrm{FEV}_{1}(\mathrm{~L})$} & Normal & $3.6 \pm 0.5^{* *}$ & - & 0.008 \\
\hline & Abnormal & $2.9 \pm 0.9^{* *}$ & - & \\
\hline & Total (44) & $3.4 \pm 0.7$ & $1.31 / 4.6$ & - \\
\hline \multirow[t]{3}{*}{$\mathrm{FEV}_{1} / \mathrm{FVC}(\%)$} & Normal & $89.9 \pm 6.2$ & - & 0.12 \\
\hline & Abnormal & $79 \cdot 3 \pm 18.1$ & - & \\
\hline & Total (44) & $87.8 \pm 0.5$ & 37.0/100.0 & - \\
\hline \multirow[t]{3}{*}{$\mathrm{FEV}_{1} / \mathrm{VC}(\%)$} & Normal & $82.8 \pm 7.2$ & - & 0.133 \\
\hline & Abnormal & $73.1 \pm 17.2$ & - & \\
\hline & Total (44) & $80.8 \pm 0.6$ & $36.0 / 95.0$ & - \\
\hline \multirow[t]{3}{*}{$\mathrm{PEF}(\mathrm{L} / \mathrm{S})$} & Normal & $6.8 \pm 1.7$ & - & 0.23 \\
\hline & Abnormal & $5 \cdot 9 \pm 2.2$ & - & \\
\hline & Total (44) & $6.6 \pm 1.9$ & $2.1 / 11.9$ & - \\
\hline \multirow[t]{3}{*}{$\mathrm{MEF}_{75}(\mathrm{~L} / \mathrm{S})$} & Normal & $6.2 \pm 1.9$ & - & 0.27 \\
\hline & Abnormal & $5 \cdot 4 \pm 2.2$ & - & \\
\hline & Total (44) & $6.1 \pm 2.0$ & $1.2 / 11.1$ & - \\
\hline \multirow[t]{3}{*}{$\mathrm{MEF}_{50}(\mathrm{~L} / \mathrm{S})$} & Normal & $5.1 \pm 1.3^{*}$ & - & 0.02 \\
\hline & Abnormal & $3.8 \pm 1.6^{*}$ & - & \\
\hline & Total (44) & $4.81 \pm 1.4$ & $0.64 / 7 \cdot 7$ & - \\
\hline \multirow[t]{3}{*}{$\mathrm{MEF}_{25}(\mathrm{~L} / \mathrm{S})$} & Normal & $2.7 \pm 1.1^{* *}$ & - & 0.008 \\
\hline & Abnormal & $1.5 \pm 0.9^{* *}$ & - & \\
\hline & Total (44) & $2.4 \pm 1.2$ & $0.34 / 5.8$ & - \\
\hline
\end{tabular}

* significant difference at $\mathrm{p}<0.05,{ }^{* *}$ significant difference at $\mathrm{p}<0.01$

Assessed variables did not show significant differences among workers reporting cardiac, hearing, and respiratory complaints and those who did not report such complaints.
Workers suffering from headaches showed a significantly higher level of cortisol and a lower mean of IL-6 at $p=0.057$

(Table 3).

Table 3: Compared means with a standard deviation of study variables between workers with and without health complaints.

\begin{tabular}{lcccccccc} 
& \multicolumn{2}{c}{ Cardiac complaints } & \multicolumn{2}{c}{ Hearing complaints } & \multicolumn{2}{c}{ Respiratory complaints } & Headache \\
& Yes & No & Yes & No & Yes & No & Yes \\
Age (52) & $41.0 \pm 6.5$ & $37.9 \pm 6.2$ & $41 \pm 8$ & $48 \pm 6$ & $41 \pm 8$ & $38 \pm 6$ & $36 \pm 6$ & $39 \pm 6$ \\
Exposure (52) & $17 \pm 6$ & $17 \pm 6$ & $17 \pm 6$ & $17 \pm 6$ & $17 \pm 6$ & $17 \pm 6$ & $15 \pm 6$ & $18 \pm 6$ \\
BMI (44) & $26 \pm 4$ & $27 \pm 4$ & $26 \pm 3$ & $28 \pm 5$ & $28 \pm 5$ & $26 \pm 4$ & $26 \pm 4$ & $28 \pm 4$ \\
SBP (46) & $136 \pm 21$ & $131 \pm 19$ & $128 \pm 23$ & $133 \pm 17$ & $131 \pm 23$ & $132 \pm 17$ & $123 \pm 20$ & $135 \pm 18$ \\
DBP (46) & $88 \pm 17$ & $83 \pm 10$ & $81 \pm 14$ & $86 \pm 11$ & $83 \pm 11$ & $84 \pm 12$ & $80 \pm 12$ & $85 \pm 12$ \\
HR (47) & $72 \pm 12$ & $77 \pm 13$ & $79 \pm 13$ & $75 \pm 13$ & $80 \pm 12$ & $75 \pm 14$ & $78 \pm 15$ & $76 \pm 13$ \\
Cortisol (50) & $232 \pm 127$ & $262 \pm 87$ & $238 \pm 94$ & $245 \pm 105$ & $216 \pm 119$ & $253 \pm 90$ & $310 \pm 53^{* *}$ & $236 \pm 98^{* *}$ \\
$\alpha$-amylase (52) & $938 \pm 268$ & $1048 \pm 232$ & $974 \pm 235$ & $1004 \pm 265$ & $997 \pm 198$ & $1004 \pm 265$ & $995 \pm 205$ & $1040 \pm 252$ \\
IL6 (45) & $0.055 \pm 0.056$ & $0.079 \pm 0.072$ & $0.07 \pm 0.06$ & $0.08 \pm 0.07$ & $0.10 \pm 0.07$ & $0.07 \pm 0.07$ & $0.05 \pm 0.05$ & $0.09 \pm 0.07$ \\
\hline
\end{tabular}

*significant difference at $\mathrm{p}<0.05,{ }^{* *}$ significant difference at $\mathrm{p}<0.01$ 
Environmental measures included particulate matter at different sites and showed to be within the approved limits as shown in Table4. Fibres concentration (with aspect ratio 3:1) was found to be $0.01 \mathrm{~F} / \mathrm{CC}$. the long axis fibres range was 9-13 micrometre and the short-axis fibres range was 2-7 micrometre. Noise levels ranged between $100 \mathrm{~dB}$ and $110 \mathrm{~dB}$ at different sites with a mean of $105.5 \mathrm{~dB}$ that is exceeding the permitted level (90 dB) (Table 4).

Table 4: Measurementsof air born particulates.

\begin{tabular}{ccc}
$\begin{array}{c}\text { Total Suspended } \\
\text { Particulates (TSP) }\end{array}$ & $\begin{array}{c}\text { Respirable Particulates } \\
\left(\text { PM }_{10}\right)\end{array}$ \\
Site 1 & $1.25 \mathrm{mg} / \mathrm{m}^{3}$ & $0.90 \mathrm{mg} / \mathrm{m}^{3}$ \\
Site 2 & $1.32 \mathrm{mg} / \mathrm{m}^{3}$ & $0.820 \mathrm{mg} / \mathrm{m}^{3}$ \\
Site 3 & $1.39 \mathrm{mg} / \mathrm{m}^{3}$ & $1.650 \mathrm{mg} / \mathrm{m}^{3}$ \\
Site 4 & $1.80 \mathrm{mg} / \mathrm{m}^{3}$ & $\mathrm{mg} / \mathrm{m}^{3}$ \\
\hline
\end{tabular}

\section{DISCUSSION}

Exposure to Particulate matter is highly associated with the serious risk of a broad variety of deteriorating health conditions. As reported, $\mathrm{PM}_{2.5}$ is the fifth-ranking mortality risk factor among air pollutants. ${ }^{21}$ Besides, different epidemiological studies ensured the link between PM exposure and cardiopulmonary mortality. ${ }^{9}$ Textile workers -in particular- are extensively exposed to PM in the working environment with certain deteriorating effects on their physical health.

Chronic respiratory symptoms have been reported by many recent studies among textile workers. TeferaZele et al..$^{22}$ assessment of respiratory symptomsin 306 cotton dust exposed workers in Ethiopia was adapted after the standard American Thoracic Society questionnaire and revealed significant differences from the control group regarding chronic chest tightness, cough, breathlessness and higher cross-shift lung function reduction in spirometry tests. A similar study on 303 male participants working in spinning and weaving sections of 5 different mills in Karachi, Pakistan reported cough, phlegm, and wheezing as respiratory symptoms. ${ }^{23}$ In Benin, 656 workers exposed to cotton dust reported cough, dyspnoea, asthma, expectorations, and chronic bronchitis that was significantly higher in frequency compared to the normal non exposed group.

In agreement with the aforementioned studies, in the present work, $33 \%$ reported the presence of respiratory complaints, and $20 \%$ showed abnormal spirometry. Lower means for all the spirometry indices and significant differences concerning FEV1, MEF50 and MEF25 were detected between workers with normal and abnormal pulmonary function tests, suggesting respiratory problems in textile workers to be of the obstructive type.

Fortunately, overall the study population is showing assumedly normal pulmonary function despite the detected problems. Upon comparing mean values of the spirometry indices with those of other exposed groups to cotton dust in similar studies it could be found that the present work reported higher $\mathrm{FEV}_{1}$ (3.4) than that reported by TeferaZele et al. $(2020)^{22}$ in Ethiopia and that stated by Hinson et al. ${ }^{24}$ in Benin.

Positive outcomes concerning pulmonary functions could be attributed to the detected particulate matter that didn't exceed the limits permitted by Egyptian environmental law 4/1994 as both parameters showed to be directly associated in a dose-response manner among textile workers. ${ }^{23}$ Moreover, workers used to stick to health safety regulations as preventive measures.

On the contrary, the noise level as detected showed to exceed the permissible limit. Such exposure could explain the increased level of cortisol among the study sample above the upper normal limit and ensures the suggested noise-induced stress. ${ }^{25}$ In accordance with the present findings Sings et al. ${ }^{26}$ proposed the stimulation of the sympathetic nervous system due to exposure to noise above $92 \mathrm{~dB}$. Additionally, in their study Melamed and Bruhis ${ }^{27}$ revealed, the effect of chronic exposure to industrial noise above $85 \mathrm{~d}$ Bon increased urine cortisol levels. Not only cortisol but also $\alpha$-amylase has shown to be increased in level in study sample exceeding the upper normal that could indicate workers suffering physiological stress. The level of $\alpha$-amylase in blood has been suggested by recent research to be responsive to the physiological and not the psychological challenge of the adrenergic system induced by stress. ${ }^{28}$

As for the inflammatory biomarker; IL-6, its mean value lied at the lower normal limit according to references; $0-16.4$ $\mathrm{pg} / \mathrm{mL}, 0-20 \mathrm{pg} / \mathrm{mL}$, and $0-31 \mathrm{pg} / \mathrm{mL}$ introduced by Khan and $\mathrm{Ali}^{29}$, Onal et al., ${ }^{30}$ and $\mathrm{Ng}$ et al. ${ }^{31}$ respectively. A critical role has been suggested by endogenous IL- 6 in the progress of lung inflammation in experimental research on mice. ${ }^{32}$ It has also been shown to be elevated in different human lung diseases involving damage in lung epithelial cells. ${ }^{33}$. Yet the very low detected level among the study sample could indicate immunosuppression. ${ }^{13}$ Besides, an inverse proportionality between cortisol and IL- 6 -resembling the present case- has been reported in different populations suffering from stress. ${ }^{34}$ Lower morning cortisol and increased IL-6, as a pattern, have been frequently observed in association with chronic stress. ${ }^{35,36}$ As per the present findings, the case is reversed and could emphasize the concluded state of acute stress expressed by cotton textile workers that could be attributed to excessive, noise, shift work, or both exposures.

The risk of lung cancer is another challenge facing textile workers due to their continuous exposure to cotton fibres yet the issue is still controversial. ${ }^{37}$. Some research studies reported positive associations like Kuzmickiene et al. ${ }^{38}$ who detected a slightly elevated incidence of lung cancer in a cohort 
sample of cotton textile workers in Lithuania. Other studies attributed the lung cancer risk to the exposure to endotoxins that varies with changes in exposure over time. For example, exposure to cotton after its processing reduces endotoxin content and hence increases the risk of lung cancer. ${ }^{39}$ Bacterial endotoxins act as protective agents against lung cancer ${ }^{40}$ and this could explain the decreased risk of lung cancer among cotton workers as compared to other types of textiles.

\section{CONCLUSIONS}

In conclusion, cotton textile workers in the present study showed to be subjected to many health hazards including noise, shift work, and chronic exposure to dust that negatively affected their health. Health consequences were prominent in the reported respiratory and hearing complaints, the abnormal spirometry, increased level of serum cortisol and $\alpha$-amylase, and reduced level of IL- 6 .

From future perspectives, continuous checkup for workers health status is crucial for their physiological wellbeing with an emphasis on the importance of management of stress and elimination of sources of excessive noise. Modulation in the shift work pattern could also help reduce health risks for cotton textile workers.

\section{List of abbreviations}

BMI: Body mass index

DBP: Diastolic blood pressure

FEV1: Forced expiratory volume in the first second

HPA: Hypothalamic-pituitary-adrenal

HR: Heart rate

IL-6: Interleukin-6

MRF:Mid expiratory flow

NRC: National Research Centre

PDF: Peak expiratory flow

PM: Particulate matter

$\mathrm{PM}_{10}:$ Respirable particulates

PM2.5: Fine particulate matter

SBP: Systolicblood pressure

TSP: Total suspended particulates

VC: Vital capacity

\section{Declarations}

Ethics approval and consent to participate

This study was approved by the ethics committee of the National Research Centre with approval number 16/401. The subject participants provided written consents.

\section{Consent for publication}

Not applicable.

\section{Availability of data and material}

The datasets used and/or analyzed during the current study are available from the corresponding author on reasonable request.

\section{Competing interests}

The authors declare that they have no competing interests.

\section{Funding}

This work was supported by the National Research Centre (NRC) [grant numbers 011010180, 2016/2019]. The NRC funded expenses for chemical kits, stationaries and transportation and offered equipment for the different measurements, analyses and examinations as well as incentives for the study team.

\section{Authors' contributions}

Prof. Dr. N.M.A. and Dr. M.S.S. were responsible for the conception and design of the study. About acquisition and interpretation of data; Prof. Dr. S.F.H. was responsible for the pulmonary function tests and history collection, Prof. Dr. Y.H.I., Prof. Dr. A.H.A.d, Dr. Y.S. were responsible for the environmental measurements and Dr. Mai SabrySaleh performed all aspects regarding biochemical analyses. Writing the manuscript was done by Dr. M.S.S. and all co-authors contributed to revising the manuscript critically and approved the final version.

\section{ACKNOWLEDGEMENTS}

Not applicable.

\section{REFERENCES}

1. International Trade Centre.International trade map online database. Geneva: International Trade Centre UNCTAD/WTO (ITC). Available online at: http://www.trademap.org/ [Accessed November 2008].

2. Ibrahim A, El-Karmalawy EM, Hassan MA, Hafez FE. Workers' Occupational Hazards at Textile Factory in Damietta City. Curr Opin Pulm Med. 2017;4(2):1-27. doi: 10.21608/ pssjn.2017.33071

3. Khan AJ, Nanchal R. Cotton dust lung diseases.Curr Opin Pulm Med. 2007;13(2):137-41.

4. Saha A, Doctor PB, Bhagia LJ, Majumdar PK, Patel B. A study of respiratory function among the workers engaged in ginning processes. Indian J Occup Environ Med. 2014;18(3):118-21. doi:10.4103/0019-5278.146908.

5. Zanobetti A, Schwartz J.The effect of particulate air pollution on emergency admissions for myocardial infarction: A multicity case-crossover analysis. Eur.Health Pract. 2005;113:978-82. 
6. Wallenborn JG, Schladweiler MJ, Richards JH,Kodavanti UP. Differential pulmonary and cardiac effects of pulmonary exposure to a panel of particulate matter-associated metals. Toxicol appl pharm. 2009;241:71-80.

7. Nemmar A, Hoet PHM, Vanquickenborne B, Dinsdale D, Thomeer M, Hoylaerts MF, et al. Passage of inhaled particles into the blood circulation in humans. Circul. 2002;105:411-4.

8. Chen H, Burnett RT, Kwong JC, Villeneuve PJ, Goldberg MS, Brook RD, et al. Spatial association between ambient fine particulate matter and incident hypertension. Circul. 2014;129:562-9. doi: 10.1161/CIRCULATIONAHA.113.003532

9. HamanakaRB, Mutlu GM. Particulate Matter Air Pollution: Effects on the Cardiovascular System. Front. Endocrinol. 2018;9:680. doi: 10.3389/fendo.2018.00680

10. Tsai DH, Amyai N, Marques-Vidal P, Wang JL, Riediker M, Mooser V, et al. Effects of particulate matter on inflammatory markers in the general adult population. Part Fibre Toxicol. 2012;9:24. doi: 10.1186/1743-8977-9-24.

11. Cosselman KE, Navas-Acien A, Kaufman JD. Environmental factors in cardiovascular disease. Nat Rev Cardiol. 2015;12:62742. doi: $10.1038 /$ nrcardio. 2015.152

12. Dube KJ, Ingale ST. Hearing impairment among workers exposed to excessive levels of noise in ginning industries. Noise Health. 2011;13(54):348-355. doi:10.4103/14631741.85506.

13. Spreng M. Possible health effects of noise-induced cortisol increase. Noise Health. 2000;2:59-63.

14. Ranawat, R. Assessment of the risk of cardiovascular and gastric problems in textile mill workers of Pali district about shift work Asian J Home Sci. 2017;12(1):42-52, doi:10.15740/HAS/ AJHS/12.1/42-52.

15. National Sleep Foundation Shift Work and Sleep. Retrieved From: https://sleepfoundation.org/sleep-topics/shift-work-andsleep/page/0/3 on 5th August 2015.

16. Williams C. Work-life balance of shift workers. Perspect. 2010;5-16.

17. Edwards C. Sixty tears after henchCorticosteroids and chronic inflammatory disease. J. Clin. Endocrinol Metab. 2012;97:144351.

18. Sealetsa OJ, Thatcher A. Ergonomics issues among sewing machine operators in the textile manufacturing industry in Batswana. J Clin Work 2011;38(3):279-89. doi:10.3233/WOR-20111131.

19. Health Education Authority Health at Work in the NHS. Building Blocks for a Healthier Workplace, Health Needs Assessment 2011

20. Asbestos and other fibres by PCM: method 7400, NIOSH Manual of Analytical Methods (NMAM), Fifth Edition, Issue 3, dated 14 June 2019 - Page 4 of 40. https://www.cdc.gov/niosh/nmam/ pdf/7400.pdf

21. Cohen AJ, Brauer M, Burnett R, Anderson HR, Frostad J, Estep K, et al. Estimates and 25-year trends of the global burden of disease attributable to ambient air pollution: an analysis of data from the Global Burden of Diseases Study 2015. Lancet. 2017;389:1907-1918. doi: 10.1016/S0140-6736(17)30505-6

22. TeferaZele Y, Kumie A, Deressa W, Moen BE, Bråtveit M. Reduced Cross-Shift Lung Function and Respiratory Symptoms among Integrated Textile Factory Workers in Ethiopia. Int $\mathbf{J}$ Environ Res Public Health. 2020;17(8):2741. doi: 10.3390/ ijerph17082741.

23. Ali NA, Nafees AA, Fatmi Z, Azam SI. Dose-response of cotton dust exposure with lung function among textile workers: MultiTex study in Karachi, Pakistan. Int J Occup Environ Med. 2018;9:120-8. doi: 10.15171/ijoem.2018.1191
24. Hinson AV, Lokossou VK, Schlünssen V, Agodokpessi G, Sigsgaard T, Fayomi B. Cotton Dust Exposure and Respiratory Disorders among Textile Workers at a Textile Company in the Southern Part of Benin. IntJ Environ Res Public Health. 2016;13(9):895. doi:10.3390/ijerph13090895

25. Zare S, Baneshi M, Hemmatjo R, Ahmadi S, Omidvar M, Dehaghi BF. The Effect of Occupational Noise Exposure on Serum Cortisol Concentration of Night-shift Industrial Workers: A Field Study. Saf Health Work. 2019;10(1):109-13.

26. Ising H, Babisch W, Kruppa B. Noise-induced endocrine effects and cardiovascular risk. Noise Health.1999;1(4):37e48.

27. Melamed S, Bruhis S. The effects of chronic industrial noise exposure on urinary cortisol, fatigue and irritability: a controlled field experiment. J Occup Environ Med. 1996;38(3):252e6.

28. Nater UM, La Marca R, Erni K, Ehlert U. Alpha-Amylase Activity in Blood Increases after Pharmacological, But Not Psychological, Activation of the Adrenergic System. PLoS One. 2015;10(6):e0130449. doi:10.1371/journal.pone.0130449

29. Khan A, Ali Z. Normal Ranges for Acute Phase Reactants (Interleukin-6, Tumour Necrosis Factor-alpha and C-reactive Protein) in Umbilical Cord Blood of Healthy Term Neonates at the Mount Hope Women's Hospital, Trinidad. West Indian Med J. 2014;63(5):465-9. doi:10.7727/wimj.2012.133

30. Onal EE, Kitapci F, Dilmen U, Adam B. Interleukin-6 concentrations in neonatal sepsis. Lancet. 1999;353:239-240.

31. Ng PC, Cheng SH, Chui KM, Fok TF, Wong MY, Wong W, et al. Diagnosis of late-onset neonatal sepsis with cytokines, adhesion molecule, and C-reactive protein in preterm very low birth weight infants. Arch Dis Child Fetal Neonatal Ed. 1997;77:F221-F7.

32. Yu M, Zheng X, Witschi H, Pinkerton KE. The Role of Interleukin-6 in Pulmonary Inflammation and Injury Induced by Exposure to Environmental Air Pollutants. Tox Sci. 2002;68(2):48897, https://doi.org/10.1093/toxsci/68.2.488

33. Rincon M, Irvin CG. Role of IL-6 in Asthma and Other Inflammatory Pulmonary Diseases. Int J Biol Sci. 2012;8(9):1281-90. doi:10.7150/ijbs.4874.Available from http:/www.ijbs.com/ v08p1281.htm

34. O'Donovan A, Hughes BM, Slavich GM, Lynch L, Cronin MT, O'Farrelly C, et al. Clinical anxiety, cortisol and interleukin-6: evidence for specificity in emotion-biology relationships. Brain, Behavior, and Immunity. 2010;24(7):1074-7. https://doi. org/10.1016/j.bbi.2010.03.003Ateya

35. Kiecolt-Glaser JK, Preacher KJ, MacCallum RC, Atkinson C, Malarkey WB, Glaser R. Chronic stress and age-related increases in the proinflammatory cytokine IL-6. Proc Nat Acad Sci USA. 2003;100:9090-5.

36. Miller GE, Chen E, Zhou ES. If it goes up, must it come down? Chronic stress and the hypothalamic-pituitary-adrenocortical axis in humans. Psychol Bull. 2007;133:25-45.

37. Ben Khedher S, Neri M, Guida F, Matrat M, Cenée S, Sanchez $M$, et al. Occupational exposure to endotoxins and lung cancer risk: results of the ICARE Study. Occup Environ Med. 2017;74(9):667-79. doi: 10.1136/oemed-2016-104117.

38. Kuzmickiene I, Didziapetris R, Stukonis M. Cancer incidence in the worker's cohort of textile manufacturing factory in Alytus, Lithuania. J Occup Environ Med. 2004;46:147-53.

39. Christensen KY, Lavoie J, Rousseau MC, Siemiatycki J. Lack of a protective effect of cotton dust on the risk of lung cancer: evidence from two population-based case-control studies. BMC Cancer. 2015;15:212.

40. Singh Z, Chadha P. Textile industry and occupational cancer. J Occup Med Toxicol. 2016;11(39). https://doi.org/10.1186/ s12995-016-0128-3 